\title{
CIVIL FORMÁK A KÖZ VÉDELMÉBEN
}

\section{Tóth Judit ${ }^{1}$}

A közrendet, közbiztonságot érintő veszélyek, kockázati tényezők és védelmi szükségletek köre folyamatosan változik. A jelenkori kihívások - mint korábbi blog-bejegyzésünkben ${ }^{2}$ már kifejtettük - újfajta megközelítést és megoldásokat igényelnek és ezzel átalakul magánszektor (köz)biztonság védelmében játszott szerepe is. Mindennek eredményeképpen a rendészeti feladatok és szervek köre folyamatosan bővül, azaz egészen eltérő képzettségü, feladatkörü emberek számára adnak felhatalmazást kényszerítő eszközök alkalmazására, hatósági intézkedések megtételére.

Bár a közigazgatás történetével foglalkozók a megmondhatói, milyen ütemben alakult ki a szakrendészet, ám az nem volt kényszerítő eszközök alkalmazására - vagy csak igen szük körben - felhatalmazva, mert intézkedéseihez, ha szükséges, igénybe vette a rendörséget. A rendőrségi törvény ${ }^{3}$ sokszoros módosításával a rendörség mára általános és szakrendészeti feladatokat egyszerre lát el. Így (a) Alaptörvényben meghatározott feladatokat (b) a határforgalom ellenörzését (c) a terrorizmus elleni küzdelmet (d) bünmegelőzést (e) bünfelderítést, bünüldözést (f) büncselekményből származó vagyon visszaszerzését, (g) államigazgatási és (h) rendészeti feladatokat. ${ }^{4}$ Ezek közt nevesítve szerepel a közterületek rendjének fenntartása; a személy-és vagyonvédelmi, magán-nyomozói tevékenység engedélyezése, felügyelete, vagy éppen az általános-és középiskolai rend fenntartásában közremüködés. Ez utóbbi a 14 éves alatti iskolakerülő gyerekek iskolába kísérését rejti, ha igazolás nélkül a tanítási napon lóg. A közterületek rendjébe tehát az iskolai lógás elleni fellépés is bekerült nemrég ${ }^{5}$, de miért kell ehhez drága pénzen kiképzett rendőr? Az valószínű, hogy ebböl a közszolgáltatásból a szegény és roma gyerekek nem fognak kimaradni. A sokrétű rendőrségi feladatok ellátásához intézkedési, titkos információ gyűjtési és kényszerítő eszközök alkalmazására vonatkozó részletes felhatalmazás társul, betekintve például a bank-, a fizetési, az értékpapír, a pénztár-, a biztosítási és az üzleti titokba, esetleg éppen azoknál a cégeknél, amelyeket korában maga engedélyezett, esetleg támogat a közfeladatok megosztása érdekében. ${ }^{6}$ A rendőrségi adatkezelés közt szereplő rendészeti adatkezelés tartalmazza pl. a sportrendészeti nyilvántartás adatait ,a közrend és közbiztonság, az erőszak és a rendzavarás megelőzése, a nemzetközi rendőrségi együttműködési kötelezettségek teljesítése, továbbá mások jogainak védelme céljából”, amelyet cégeknek és vállalkozóknak is továbbíthat (pl. a sportrendezvényről kitiltás, látogatásától eltiltás, jegyvásárlás akadályozása érdekében a sportszervezőknek, jegyárusoknak). ${ }^{7}$ Ez alapvetően tehát for-profit sportvállalkozásoknak és

\footnotetext{
${ }^{1}$ Tóth Judit CSc., tszv. egyetemi docens, SZTE ÁJK.

2 TóTH Judit: Közrendészet és magánrendészet - új szövetségben, Közjavak.hu, 2016.

3 1994. évi XXXIV. törvény a Rendörségröl.

${ }^{4}$ Rtv. 1.\$.

${ }^{5}$ Rtv. 34/A. § (1) és (2) bek.

${ }^{6}$ Rtv. 68.§.

${ }^{7}$ Rtv. 91/J. .
} 
szervezö ügynökségeknek áll érdekében, hogy a közpénzből müködő rendőrök nekik adatokat adjanak sportügyi bűnözők vagy szabálysértők kiszüréséhez, de a kaszinóknak, a kocsmáknak és diszkóknak már nem, pedig a kitiltás ott is érvényesítendő. Vajon miért a közigazgatási adatkezelés közt húzódik meg a hozzátartozók közti erőszak alapján hozott ideiglenes megelőző távoltartó határozattal érintettek adata, túl a formális eljárási besoroláson? Ki gondolja, hogy a családtagjaival erőszakos ${ }^{8}$ kevésbé veszélyes, mint a közvagyonba tartozó metrót szétverő drukker? Igaz, a szegény családokból a hivatalos szóhasználat szerinti „perpatvarhoz” többször hívják a rendőrséget, mint a tehetősebbek, mert ők magántestőrt fogadnak, vagy adatot magánnyomozóval gyűjtetnek családtagjukról.

A rendészeti feladatokat (is) ellátó szervek köre ${ }^{9}$ pedig egyre szaporodik. Ma ilyen tevékenységet végeznek, az (általános rendőrség, TEK és a védelmi szolgálat miatt háromfejü vált) rendőrségen kívül a természetvédelmi őrök; az erdővédelmi szolgálat tagjai; a hegyőrök; a mezőőrök; a halászati őrök; az önkormányzati természetvédelmi őrök; a rendészeti feladatokat ellátó erdészeti szakszemélyzet tagjai; a közterület-felügyelők; a hivatásos vadászok, akik intézkedési és kényszerítő-eszközök használatára kapnak jogot, a nekik szóló törvényi feladatok (pl. szabálysértési eljárásban intézkedés) ellátásához. ; a fegyveres biztonsági őrök (a formaruházat tekintetében), a személy-és vagyonőrök.

Látható, hogy nem egységes a jogállásuk, és különbözőek a követelmények az egyes csoportokkal kapcsolatosan, ideértve azt is, hogy például a mezőőri szolgálat költségeit, amely a földhasználók (vagyis döntően a magántulajdon és a magánbiztonság) érdekében müködik, fele részben a központi költségvetés biztosítja, csak a másik felét fizetik a földhasználók, miközben a hegyközségek szőlőtulajdonosai fizetik a hegyőrt, bár felügyeletét a rendőrkapitányság látja el. Igaz, a biztonsági- és a vagyonőrök kivételével, a közszolgálati vagy közalkalmazotti jogviszonyban álló személy munkáltatója, az illetékes megyei (fővárosi) rendőr-fökapitánysággal, a rendészeti feladatokat ellátó személyek ellenőrzése és törvényben meghatározott tevékenységük felügyelete, valamint a feladatellátás összehangolása érdekében - írásbeli együttmüködési megállapodást köt. Ebben feltehetőleg rögzítik a köz- és magánbiztonság közös és közösen finanszírozható pontjait. Így válhat legitim módon a magánrendészet a közrend védelmezőjévé.

I. Ezek fényében érthető, miért viszonylagosan autonóm a magánbiztonsági vállalkozásokat és dolgozókat tömörítő kamara ${ }^{10}$, amely kényszertagság nélkül is állami kitartottnak tekinthető szakmai érdekképviselet. A Kamara ,a személy-és vagyonvédelmi, valamint a magánnyomozói tevékenység folytatására jogosult természetes személyek önkormányzattal rendelkező, közfeladatot és általános szakmai érdekképviseleti feladatokat ellátó köztestülete.

A kamara közhasznú szervezet, mivel tevékenysége során olyan közfeladatot lát el, amely jogszabályban meghatározott állami feladat, és amelyet közérdekből, haszonszerzési cél nélkül végez, közfeladat teljesitését közvetlenül szolgálja, ezzel hozzájárulva a társadalom és az egyén közös szükségleteinek kielégítéséhez. Az országos szervezet jogosult Magyarország

\footnotetext{
${ }^{8}$ Hírek, Közjavak.hu.

9 2012. évi CXX. törvény az egyes rendészeti feladatokat ellátó személyek tevékenységéről, valamint egyes törvényeknek az iskolakerülés elleni fellépést biztosító módosításáról.

${ }^{10}$ Személy-, Vagyonvédelmi és Magánnyomozói Szakmai Kamara.
} 
címerének használatára is” köztestületként, bár a törvény ${ }^{11}$ alapján csak „hivatali feladataik ellátása során". A mindenhol elhelyezett címer azt a látszatot keltheti a laikusokban, hogy e vállalkozásokat képviselö kamara valamilyen hivatalosság. A kamara feladatai ${ }^{12}$ közt szerepel, hogy közremüködik a törvény (2005) hatálya alá tartozó tevékenységek gyakorlásának jogszabályai, szakmai irányelvei, a szolgáltatások teljesítésének szakmai követelményeire vonatkozó ajánlások, rezsióradíj-minimum kidolgozásában; megváltoztatásában; továbbá a jogszabályban meghatározott szakképesítések tekintetében a rendészetért felelős miniszterrel kötött megállapodás alapján, kidolgozza és gondozza a szakmai és vizsgakövetelményt, a szakmai minősítő rendszert; közremüködik a szakképzésben és a vizsgáztatásban, javaslatot ad a szakmai vizsgáztatásban és annak ellenőrzésében szakértőként kirendelhető személyekre.

A kamarai tagság előfeltétele a rendőrség által kiadott szakmai igazolvány illetve a müködési engedély, esetleg a tervező-szerelő vagy magánnyomozói tevékenységet végző vállalkozás bejelentése - azaz együttesen a rendőrségi jóváhagyás és a felelősség biztosítás, és nem legitim a szolgáltatása, ha a jóváhagyást a rendőrség visszavonta. Vajon más nem tudja az érdekvédelmet ellátni? Az csak ilyen igazolvány, jóváhagyás alapján teljesíthető? A szakmai önkormányzásban más is segíthetne.

Napi szinten jelzi a szimbiózist a köz-és magánbiztonsági szereplők közös rendezvényeinek sora. Például a húsz éve alapított Magyar Biztonsági Vezetők Egyesületében ${ }^{13}$, ahol az ünnepi rendezvény ${ }^{14}$ „a vállalkozásbiztonságot érintő legaktuálisabb előadások mellett megint lehetöséget adott a megrendelöi és a vállalkozói oldal képviselöinek arra, hogy két napig közvetlenül konzultálhassanak egymással a magánbiztonság kérdéseiröl. Az eseményen a magánbiztonsági iparág vezetőin kivül részt vettek a Belügyminisztérium és a Terrorelhárítási Központ prominensei és áttekintik az iparág szerepét a terrormegelözésben." De szó esett még a magánbiztonsági oktatás helyzetéről, a pénzintézeti biztonságról, a személyazonosítás biometriai lehetőségeiről, az információ biztonságról a terrorizmus ellen, a drónok használatáról és a robbanóanyagok-robbanószerkezetek bủnös célú felhasználása elleni védelemről.

A kamara honlapjáról az is kiderül, hogy rendszeres a piaci szereplők hatósági tájékoztatása (például a magánbiztonsági tevékenység hatósági engedélyezésének szabályozásáról, a hatósági ellenőrzések tapasztalatairól), így nincs gond azzal, hogy mi a közérdekű adat, Érezhető, hogy a (személy/vagyon) biztonság védelme erős kapocs, és a hasonlóan szoros, befolyásos együttmüködésre nincs példa más szektorban, például a köz-és magánoktatás vagy a köz-és magánmédia között.

A kamarai tagoknak meglehetősen sok jogszabály ${ }^{15}$ ismeretét kell bizonyítaniuk a szakmai vizsgán, bár az alapjogi, emberi jogi követelmények, az Európai Unió szolgáltatási, vállalkozási szabályai abban nem vagy alig bukkannak fel, holott számos példa ${ }^{16}$ hozható

\footnotetext{
${ }^{11}$ 2011. évi CCII. törvény Magyarország címerének és zászlajának használatáról, valamint állami kitüntetéseiröl, $1 . \S$.

${ }_{12}$ A Személy-, Vagyonvédelmi és Magánnyomozói Szakmai Kamara Alapszabálya.

${ }_{13}^{13}$ Magyarországi Biztonsági Vezetök Egyesülete.

${ }_{14} 20$ éves az MBVE, Detektor magazin.

15 Jogszabályok jegyzéke.

${ }^{16}$ A példák az alábbi linken érhetők el.
} 
arra, hogy nagyon kell ismerni az alapvetö és az emberi jogok alkotmányos, nemzetközi jogi határait a magánrendészeti munkát végzőknek. Lehetséges, hogy mindezt ismertnek tekintik, hiszen a közrendészetből átcsábulók vagy bedolgozók jelenlétét feltételezik, ők pedig azt már ismerik. Ráadásul az összes állami rendészeti képesitést, de még az 1960-tól kiadott üzemrendészeti oklevelet ${ }^{17}$ is a magánbiztonsági iparban el kell fogadni. Noha a kamarai törvény (2005) értelmében, a rendőrség és a polgári nemzetbiztonsági szolgálatok személy-és vagyonvédelmet, tervezést-szerelést hatósági jogkörben ellátó (hivatásos vagy polgári állományú) munkatársa nem lehet tagja, vezető tisztségviselője, tagja ilyen vállalkozásnak, személy-és vagyonvédelmet, szerelést-tervezést vállalkozás keretében nem végezhet, ám a kettős minőség tilalma feloldható, ha az állományilletékes parancsnok engedélyezi a vállalkozás keretében e munkát. Vajon miért nem félnek a korrupciótól, a bün elkövetésétől, hogy nem tekintik összeférhetetlennek a vagyonvédelmi rendszert tervező és szerelő tevékenységre, az ingatlan, illetve ingóság örzésre, a szállítmány kísérésére, pénz és érték szállítására vonatkozó rendőri, titkos-szolgai külön munkát? Csak nem azért, mert úgyis kevés a hivatásosok jövedelme? Ahogy a mentősök, a nővérek és az egyetemi oktatók is több állást halmoznak fel a megélhetéshez, így a közkassza is jól jár a kevesebb fizetéssel és a dolgozók is a külön jövedelmekkel? Csak éppen a minőségi és számon kérhető munka, azaz a köz láthatja ennek a kárát.

Az összeférhetetlenség nem merül fel abban sem, hogy az engedélyt kiadó és a vállalkozások müködését ellenőrző, a személy-és vagyonőrzést, magánnyomozást végző, irányító számára felügyeleti bírságot (pl. igazolvány nélküli munkavégzésért, a müködési szabályok megsértéséért) is kiszabó hatóság feje, azaz a rendészeti (belügy) miniszter látja el a kamara felett a törvényességi felügyeletet. Vajon miért nem az ügyészség, mint sok más köztestület és általában a civil szervezetek esetében? Összegezve, a rendőrség engedélyez, felügyel, bírságol, vizsgáztat, képesítésekről, kettős jogviszonyról dönt az egyes vállalkozók, dolgozók esetében, együttmüködik, tájékoztat, míg a kamara törvényes müködése felett a belügyminiszter őrködik. Az állami szabályozás pedig nem csak jelentős alapjog-korlátozó hatásköröket ad, egyre szélesebb körben, a magánrendészeti szervezeteknek, de még a minimális rezsióradíjat ${ }^{18}$ is megszabja számukra. Vajon ezzel az árversenyt akarják korlátozni vagy a közbeszerzési pályázókat segíteni?

II. „Magyarországon a Polgárörség nélkül nincs közbiztonság, nincs bünmegelözés.” A Polgárörség ${ }^{19}$ eredményeit, sikereit elismerik az ország vezetői, Magyarország Kormánya, Belügyminisztere, a Rendőrség vezetői, akik mindezek mellett stratégiai partnerként is kezelik a Polgárörséget. Ennek bizonyítéka, hogy technikai fejlesztéséhez támogatást kap a költségvetésből valamennyi egyesületnél, szövetségnél, külön törvény szól a polgárörségről, van egységes formaruha, polgárőr igazolvány, gépjármü megjelenés, a képzésüket szolgáló

\footnotetext{
${ }^{17}$ 22/2006. (IV. 25.) BM rendelet a személy- és vagyonvédelmi, valamint a magánnyomozói tevékenység szabályairól szóló 2005. évi CXXXIII. törvény végrehajtásáról.

${ }^{18} 360 / 2014$. (XII. 30.) Korm.rendelet a 2015. évre vonatkozó, a személy- és vagyonvédelmi, valamint magánnyomozói tevékenység szabályairól szóló törvény szerinti minimális vagyonvédelmi szolgáltatási rezsióradíj mértékéröl.

${ }^{19}$ 2011. évi CLXXV. törvény az egyesülési jogról, a közhasznú jogállásról, valamint a civil szervezetek támogatásáról.
} 
Polgárör Akadémia. ${ }^{20}$ A Polgárőrség az elmúlt 25 év alatt amatőr bűnmegelőzési szervezetből, fél profi, profi bünmegelőző szervezetté vált, a rendészeti család tagjai 55 ezer fős létszámával, ,akik napról napra önkéntes munkájukkal járulnak hozzá Magyarország köznyugalmához". ${ }^{21}$ Ök a magán- vagy a közbiztonságot szolgálják civil szervezetként? Miért csak ők a stratégiai partnerek?

Olyan szervezetről van szó, amelynek formáját törvény írja elő (egyesület, megyei és országos szövetség), ilyenként müködésének előfeltétele az egységes szövetségbe belépés és a megyei rendőr-főkapitánysággal való együttműködési megállapodás megkötése. Nem elég, hogy alapvető feladatait törvényben írják elő, de az egyesülési jogot abban is korlátozzák, hogy jogi személyiség létesítését a közrendészet (közigazgatási szerv és nem bíróság) döntésétől is függővé teszik, sőt a helyi közrend és közbiztonság védelmét, valamint a bűnmegelőzésben való közremüködést végző magánemberekből állók civil szerveződése kizárólag ebben a formációban müködhet. Az egyesülési jog súlyos korlátozásaként kizárólagosságot adtak nekik törvényben, mivel az alapfeladatait (cél szerinti tevékenységét) „más társadalmi szervezet nem végezheti, ilyen célra más társadalmi szervezet nem alapítható". Mivel közterületen végzi a figyelést, járörözést, nem a polgárok saját, hanem a közvagyon és közrend települési védelmét akarja alapvetően ellátni, és csak kiegészítő tevékenységként védi, nevének megfelelően, a magánvagyonok, sérülékeny emberek (idősek, fogyatékosok, baleseti sérültek) életét, javait. A nem-civilséget erösíti, hogy a törvény tényleges hatósági jogalkalmazási feladatot is rábíz a polgárőrökre: azok közremüködnek a közterületen közbiztonsági, bűnmegelőzési, valamint bünüldözési célból elhelyezett képfelvevő által rögzített felvételek megfigyelésében, a körözött tárgyak, személyek és holttestek azonosításában és felkutatásában, valamint a közforgalmú vasúti személyszállítási szolgáltatás rendjének biztosításában. Ez személyes adatkezelést és veszélyes köz/üzemek területére belépést is biztosan magába foglal, amelyre csak ez a törvény adott számukra felhatalmazást, de más alapjogi, munkajogi, közlekedési jogszabály biztosan nem. Attól, hogy van rendőrségi együttműködési megállapodásuk, ez a tevékenység nem lesz alkotmányos, hiszen hiányzik a közhatalom gyakorlásának számon kérhetősége és a közjogi felelősség. Így ez a civilekre delegálás alkotmányosan vitatható. Ez folytatása a közhasznúsági szervezeti besorolás alapjaként megkövetelt, az állam vagy az önkormányzat helyetti (segít/közremüködik kifejezések mögé bújva) feladatellátásnak. Érthető, ha az Országos Polgárör Szövetség ,az önkormányzás elvén alapuló közhasznú jogállású köztestület. Az Országos Polgárör Szövetség névhasználatára kizárólag az e törvény által létrehozott köztestület jogosult." A törvény erejénél fogva, nem kell nekik bajlódni a közhasznú szervezetek ezreit megnyomorító feltételek ${ }^{22}$ igazolásával, azaz a monopólium a tevékenységükre, a jogállásra és a névhasználatra egyaránt kiterjed. Ezt támogatja meg a garantált közpénzügyi apanázs: a költségvetési törvényben nevesített pénztámogatás, valamint a központi költségvetésből finanszírozott formaruha, védőmellény, valamint a velük együttmüködő hatóságoktól ingyen kapott eszközök. ${ }^{23}$

\footnotetext{
${ }^{20} 25$ éves a polgárörség.

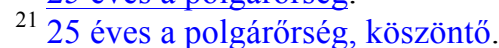

22 2011. évi CLXXV. törvény az egyesülési jogról, a közhasznú jogállásról, valamint a civil szervezetek müködéséről és támogatásáról.

${ }^{23} 2011$. évi CLXV. törvény a polgárőrségről és a polgárőri tevékenység szabályairól, 3-4.§, 8.§ és $26 . \S$.
} 
De akkor mitől civil? Attól, hogy van alapszabálya, és esetleg azért, mert az Országos Polgárőr Szövetség feletti törvényességi ellenörzést az ügyészség gyakorolja. Mindenesetre mind a Polgárőrség, mind pedig a Kamara példája jól érzékelteti a köz-és a magánbiztonság összenövését, és ezzel együtt a magánjogi keretek között létrejött formák körének bővülését a rendészeti feladatellátás terén. Számos további kérdés merülhet fel e "szimbiózis" finanszírozásával, a köz-és magánpénzek szerepével összefüggésben - amelyeket már egy következő bejegyzésben érdemes megvizsgálni... 